\title{
Predictors of Adolescent Academic Achievement: The Role of Individual and Family Socioeconomic Factors
}

\author{
Melly Latifah ${ }^{1 *}$, Rizky Amelia ${ }^{2}$ \\ ${ }^{1,2}$ Department of Family and Consumer Sciences, Faculty of Human Ecology, IPB University, \\ Bogor 16680, West Java, Indonesia \\ *) Corresponding author: mellylatifah@gmail.com
}

\begin{abstract}
Academic achievement is affected by external and internal factors. This study generally aims to examine the influence of family characteristics (per capita income and parental education), individual characteristics (age and gender), cognitive intelligence, and self-regulated learning toward academic achievement in adolescents. A total of 91 samples $\left(\mathrm{M}_{\mathrm{age}}=13.9\right.$ years $)$ with the largest percentage of the respondents were women were selected from two different junior high schools in Bogor area. Cognitive intelligence, self-regulated learning, and academic achievement were measured using Riley Inventory Basic of Learning Skills (RIBLS), Motivated Strategies for Learning Questionnaire (MSQL), and student academic record, respectively. The partial regression analysis showed there was a negative effect of mother's education on self-regulated learning. Gender was found to positively predicted cognitive intelligence. The regression analysis also showed that parental education and cognitive intelligence positively predicted adolescent academic achievement. Per capita income, gender, and self-regulated learning showed no significant effects on academic achievement.
\end{abstract}

Keywords: academic achievement, adolescent, cognitive ability, self-regulated learning

\begin{abstract}
Abstrak
Prestasi akademik dipengaruhi oleh faktor eksternal dan internal. Penelitian ini secara umum bertujuan untuk melihat pengaruh karakteristik keluarga (pendapatan dan pendidikan orang tua), karakteristik individu (usia dan jenis kelamin), kecerdasan kognitif, dan self-regulated learning terhadap prestasi akademik remaja. Sebanyak 91 responden (Rata-rata usia=13.9 tahun) dengan persentase terbesar berjenis kelamin perempuan dipilih dari dua SMPN yang berbeda di wilayah Bogor. Analisis menggunakan uji regresi linear. Hasil analisis regresi parsial menunjukkan lama pendidikan ibu berpengaruh negatif terhadap self-regulated learning. Jenis kelamin berpengaruh positif terhadap kecerdasan kognitif. Hasil analisis regresi juga menunjukkan pendidikan orang tua dan kecerdasan kognitif remaja berpengaruh positif terhadap prestasi akademik. Sementara itu, pendapatan per kapita, jenis kelamin, dan self-regulated learning tidak berpengaruh signifikan terhadap prestasi akademik.
\end{abstract}

Kata kunci: kecerdasan kognitif, self-regulated learning, prestasi akademik, remaja 


\section{Introduction}

Good learning outcomes are the main goal of a learning process in schools as measured by the academic achievements of students in various fields. However, empirical facts show that the learning achievements of students in Indonesia are still far from satisfying. This can be seen from the results of the 2018 Program for International Student Assessment (PISA) research - involving 78 countries - announced by The Organization for Economic Co-operation and Development (OECD, 2018). The results show a low mathematical ability of adolescent students in Indonesia (ranked 72 with a score of 379, while the average score of OECD countries is 489). Similar findings are found in the ability in science (rank 70 with a score of 396, while the average score of OECD countries 489 ) and literacy reading (rank 72 with a score of 371, while the average score of OECD countries 487). The fact that the learning outcomes of adolescent students are still low indicates that it is important to conduct a study of the factors that affect adolescent academic achievement.

Academic achievement is the result of a learning process that is determined by many factors, one of which is the role of individual factors of students and their families (Santrock, 2011). Individual factors (such as cognitive abilities, self-regulation strategies in learning, gender), and family factors (such as family socioeconomic status) play an important role in the achievement of students' academic achievement (Clemons, 2008). Many research results prove the role of individual factors in academic achievement. Cognitive ability is one of the individual factors that play an important role in academic achievement (including, Diniz, Pocinho, \& Almeida, 2011; Rohde \& Thompson, 2007; Rosopa \& Schroeder, 2009).

In addition, self-regulated learning (SRL) is also considered important for the academic achievement (Santrock, 2011). In the concept of generative learning, SRL is a metacognitive skill that reflects how thoughts, feelings, and actions are generated by oneself, planned and adapted continuously to achieve learning goals; includes learning motivation and learning strategies (Zimmerman \& Schunk, 2001; Zimmerman, 2000). The results of the study prove that academic achievement is correlated with self-regulation strategies in learning (Amalia \& Latifah, 2019). From the results of the text reading test it was found that the self-regulation strategy in the learning of junior high school students with high academic achievement was better than students with low academic achievement (Latifah, 2002). Other studies have shown that self-regulation strategies in learning influence academic achievement (Mega, Ronconi, \& De Beni, 2014; Novianti, Latifah, \& Hernawati, 2018; Novita \& Latifah, 2014; Situmorang \& Latifah, 2014). The results of other studies indicate that adolescents of a certain sex are believed to have different cognitive intelligence (Nyborg, 2005) and different self-regulated learning (Kurman, 2004). Novita and Latifah's research (2014) also shows that gender influences adolescent academic achievement. Thus, it can be assumed that gender is an individual factor that can determine academic achievement.

In addition to individual factors, socio-economic factors are also thought to determine children's academic achievement. Several studies have shown that family background has direct and indirect effects on children's academic achievement (including, Diniz et al., 2011). The results of Castillo et al. (2011) showed a positive relationship 
between education and adolescent cognitive abilities. The results of Situmorang and Latifah (2014) research also showed the effect of parental education on self-regulation strategies in learning. Meanwhile, the results of Theresya, Latifah, and Hernawati (2018) research showed that fathers education influenced adolescent academic achievement. The results of Stull's research (2013) show the effect of parents' socioeconomic status (SES) on children's learning outcomes. Thus, it can be hypothesized that family SES factors predict adolescent academic achievement.

Based on this, this study aims to (1) identify individual factors (gender, cognitive abilities, and SRL), family factors (education and family income), and adolescent academic achievement; and (2) analyze the influence of individual and family SES factors on adolescent academic achievement.

\section{Methods}

\section{Participants}

This study used a cross-sectional study design which was conducted at two State Junior High Schools (SMPN) located in the City and Regency of Bogor. SMPNs located in cities are marked with SMP X while SMPNs located in districts are marked with SMP $Y$. The selection of the location was done purposively based on consideration of the two schools having diversity in students' academic abilities by having class VIII which are all regular classes.

The population of this study was students of SMP X and Y. Samples of this study were regular 8th graders from each school. Grade 8 sampling was based on the consideration that class 8 , unlike class 9 , is not preoccupied with preparation for the National Final Examination and has had a long experience of studying in junior high compared to class 7. Samples from SMP X and SMP Y were each taken 54 adolescents by a simple random sampling technique in which this number was taken based on consideration of the minimum number to carry out statistical tests. However, after doing cleaning data only 91 adolescents were taken as samples in this study. The reduction in the sample quota is because some samples could not and were not willing to complete the required data.

\section{Measures}

Primary data were collected with the help of instrument tools and secondary data were obtained from the school. Primary data included family characteristics (income and parental education), individual characteristics (age and gender), cognitive intelligence, and self-regulated learning. Secondary data included the number of students and student academic achievements obtained through report cards. Self-regulated learning was measured using the Motivated Strategies for Learning Questionnaire (MSLQ; Pintrich et al., 1991). Self-regulated learning is composed of two dimensions, namely motivation and student learning strategies containing 81 questions answered using a 1-7 Likert scale (1=strongly disagree; $2=$ disagree; $3=$ somewhat disagree; $4=$ neutral ; $5=$ somewhat agree; $6=$ agree; and $7=$ strongly agree). The reliability of the self-regulated learning questionnaire was 0.878 . 
Cognitive intelligence was measured using standard instruments of Riley Inventory Basic of Learning Skills (RIBLS; Riley, 1992) and developed by Latifah and Dina (2002). This instrument measures seven dimensions of cognitive intelligence, namely visual memory, auditory sequencing, auditory memory, vocabulary, integration, kinesthetic learning, and concetration. The assessment of cognitive intelligence level is based on the RIBLS standard which is classified into five categories, which is far below average $(<7.0)$, below average (7.1-9.0), average (9.1-11.0), above average (11.1-13.0) and far above the average (>13.0).

Academic achievement data were viewed using student report cards obtained from the school. Academic achievement can be seen from the average value of sample report cards in seventh grade the second semester presented in two categories; above average and below average.

\section{Analysis}

The obtained data were processed through the stages of editing, coding, scoring, entering, cleaning, and analyzing. Data processing was performed using Microsoft Excel software while data analysis was performed using Statistical Package for Social Science (SPSS) software. Data analysis included descriptive and inferential tests. The descriptive test was employed to obtain the average value, standard deviation, minimum, and maximum values of research variables. The inferential test included linear regression tests to measure the influence of family SES characteristics, individual characteristics, selfregulated learning, and cognitive intelligence on academic achievement.

$$
\mathrm{Y}=\mathrm{a}+\mathrm{b} 1 \mathrm{X} 1+\mathrm{b} 2 \mathrm{X} 2+\mathrm{b} 3 \mathrm{X} 3+\mathrm{b} 4 \mathrm{X} 4+\mathrm{b} 5 \mathrm{X} 5+\mathrm{b} 6 \mathrm{X} 6
$$

where:

Y : Academic achievement

a : constant

b1 : regression coefficient of variable X1

X1 : father's length of education

b2 : regression coefficient of variable X2

X2 : mother's length of education

b3 : regression coefficient of variable X3

X3 : per capita income

b4 : regression coefficient of variable X4

X4 : adolescent gender

b5 : regression coefficient of variable X5

X5 : cognitive intelligence

b6 : regression coefficient of variable X6

X6 : self-regulated learning 


\section{Findings}

\section{Adolescents Characteristics and Family Socioeconomic Characteristics}

Family socioeconomic characteristics and adolescent characteristics in this study are illustrated in Table 1 and Table 2 respectively. The results found that per capita income and parental education in this study varied. Families had an average per capita income of Rp1,158,081.7. The average length of education of fathers was 12.1 years and the average length of education of mothers was 11.6 years. Meanwhile, the average age of adolescents was 13.9 years. As many as $53.8 \%$ of adolescents in this study were female.

Table 1 . Sample distribution by family characteristics $(n=91)$

\begin{tabular}{|c|c|c|c|c|}
\hline \multirow{2}{*}{\multicolumn{5}{|c|}{$\frac{\text { Variable }}{\text { Family income }(\mathrm{Rp})}$}} \\
\hline & & & \multirow{2}{*}{\multicolumn{2}{|c|}{81.3}} \\
\hline $600,000-7,680,000$ & \multicolumn{2}{|c|}{74} & & \\
\hline $7,680,001-14,760,000$ & \multicolumn{2}{|c|}{12} & \multicolumn{2}{|c|}{13.2} \\
\hline $14,760,001-21,840,000$ & \multicolumn{2}{|c|}{3} & \multicolumn{2}{|c|}{3.3} \\
\hline $21,840,001-28,920,000$ & \multicolumn{2}{|c|}{1} & \multicolumn{2}{|c|}{1.1} \\
\hline $28,920,001-36,000,000$ & \multicolumn{2}{|c|}{1} & \multicolumn{2}{|c|}{1.1} \\
\hline Min-max & \multirow{2}{*}{\multicolumn{4}{|c|}{$\begin{array}{c}600,000-36,000,000 \\
5,265,279 \pm 5,382,895.2\end{array}$}} \\
\hline \multirow[t]{3}{*}{ Mean \pm SD } & & & & \\
\hline & \multicolumn{2}{|c|}{ Father } & \multicolumn{2}{|c|}{ Mother } \\
\hline & $\mathrm{n}$ & $\%$ & $\mathrm{n}$ & $\%$ \\
\hline \multicolumn{5}{|l|}{ Parental education (year) } \\
\hline Not completed primary school & 4 & 4.4 & 1 & 1.1 \\
\hline Graduated from elementary school & 10 & 11.0 & 15 & 16.5 \\
\hline Graduated from middle school & 10 & 11.0 & 12 & 13.2 \\
\hline Graduated from high school & 43 & 47.3 & 49 & 53.8 \\
\hline Graduated from 4-year college & 19 & 20.9 & 13 & 14.3 \\
\hline $\begin{array}{l}\text { Graduated from post-graduate } \\
\text { school or more }\end{array}$ & 5 & 5.5 & 1 & 1.1 \\
\hline Min-max & \multicolumn{2}{|c|}{$0-2$} & \multicolumn{2}{|c|}{$2-18$} \\
\hline Mean \pm SD & \multicolumn{2}{|c|}{$12.1 \pm 4.2$} & \multicolumn{2}{|c|}{$11.6 \pm 3.5$} \\
\hline
\end{tabular}

Table 2. Sample distribution by adolescent characteristics $(\mathrm{n}=91)$

\begin{tabular}{|c|c|c|}
\hline Variable & $\mathrm{n}$ & $\%$ \\
\hline \multicolumn{3}{|l|}{ Gender } \\
\hline Male & 42 & 46.2 \\
\hline Female & 49 & 53.8 \\
\hline \multicolumn{3}{|l|}{ Age (year) } \\
\hline 13-13.11 & 37 & 40.7 \\
\hline 14.14 .11 & 53 & 58.2 \\
\hline$>15$ & 1 & 1.1 \\
\hline Min-mx & \multicolumn{2}{|c|}{$13.0-15.4$} \\
\hline Mean \pm SD & \multicolumn{2}{|c|}{$13.9 \pm 0.5$} \\
\hline
\end{tabular}

\section{Cognitive Intelligence}

In general, half of the adolescents in this study (50.5\%) had cognitive intelligence on an average category. As many as $27.5 \%$ and $34.1 \%$ of the adolescents had the ability of 
kinesthetic learning and concentration, that is, the ability to learn the forms of change and pay attention to certain stimuli with categories far above average. Other adolescent capabilities were in the dimensions of visual memory (100\%) and integration (51.6\%), that is, the ability to recall visual patterns and combine several processes with categories far below average. Other abilities of adolescents in the auditory sequencing dimension $(56.0 \%)$ are the ability to recall the sequence of information they have heard which is average. The ability of auditory memory (46.2\%), that is the ability to mention information that has been heard was above average and the ability of vocabulary (94.5\%), that is the ability related to how much knowledge the person has about the words they know as below average.

Table 3. Sample distribution by cognitive intelligence $(n=91)$

\begin{tabular}{lccccc}
\hline \multirow{2}{*}{ Dimension } & \multicolumn{3}{c}{ Frequency (\%) } \\
\cline { 2 - 6 } & $\begin{array}{c}\text { Far below } \\
\text { average }\end{array}$ & $\begin{array}{c}\text { Below } \\
\text { average }\end{array}$ & Average & Above average & $\begin{array}{c}\text { Far above } \\
\text { average }\end{array}$ \\
\hline Visual memory & 100.0 & 0.0 & 0.0 & 0.0 & 0.0 \\
Auditory sequencing & 14.3 & 22.0 & 56.0 & 1.1 & 6.6 \\
Auditory memory & 4.4 & 6.6 & 18.7 & 46.2 & 24.2 \\
Vocabulary & 5.5 & 94.5 & 0.0 & 0.0 & 0.0 \\
Kinesthetic learning & 15.4 & 17.6 & 20.9 & 18.7 & 27.5 \\
Integration & 51.6 & 18.7 & 17.6 & 18.7 & 0.0 \\
Concentration & 0.0 & 17.6 & 29.7 & 6.6 & 0.0 \\
Total & 6.6 & 36.3 & 50.5 & & 34.1 \\
\hline
\end{tabular}

\section{Self-regulated Learning}

The average achievement of self-regulated learning of the adolescents was in the medium category. This is explained by the achievements of each dimension where the average achievement was moderate (motivation 70.2 and learning strategy 65.0). When viewed based on the subdimension of the motivation, the highest achievement was the extrinsic goal orientation and the lowest achievement was the exam anxiety. When viewed based on the subdimension of the learning strategy, the highest achievement was seeking assistance and the lowest achievement was the time management/learning environment. 
Table 4. Sample distribution by self-regulated learning achievements $(n=91)$

\begin{tabular}{lcc}
\hline Dimension & Mean & Min-Max \\
\hline Motivation & 70.2 & $56.5-88.2$ \\
Intrinsic goal orientation & 70.2 & $45.8-100.0$ \\
Extrinsic goal orientation & 82.9 & $50.0-100.0$ \\
Assignment grade & 68.8 & $47.2-86.1$ \\
Control over trust in learning & 78.7 & $54.2-100.0$ \\
Trust in learning and achievement & 67.9 & $39.6-93.8$ \\
Exam anxiety & 58.8 & $16.7-93.3$ \\
\hline Learning strategy & 65.0 & $43.7-83.3$ \\
Practice & 67.3 & $37.5-100.0$ \\
Elaboration & 67.4 & $44.40-94.4$ \\
Organizing & 67.5 & $33.3-95.8$ \\
Critical thinking & 66.5 & $50.0-96.7$ \\
Metacognition in self-regulation & 63.3 & $41.7-83.3$ \\
Time management / learning & 61.4 & $35.4-100.0$ \\
environment & & \\
Arrangement in trying & 66.3 & $33.3-100.0$ \\
Learning from the peer & 62.8 & $22.2-94.4$ \\
environment & & \\
Search for help & 67.8 & $45.8-100.0$ \\
\hline Total & 67.0 & $51.2-80.9$
\end{tabular}

Note. $<60=$ low, $60-80=$ moderate, $>80=$ high

\section{Academic Achievement}

Academic achievement in this study was obtained from the report card grade 7 second semester. Subjects seen were ten subjects in two schools whose results are shown in Table 2. The results showed more than half of the adolescents (51.6\%) had academic achievement above average.

Table 5. Sample distribution by academic achievement in grade 7 second semester $(\mathrm{n}=91)$

\begin{tabular}{lcc}
\hline Category & $\mathrm{n}$ & $\%$ \\
Below average & 44 & 48.4 \\
Above average & 47 & 51.6 \\
\hline Mean \pm std & & $78.5 \pm 3.9$ \\
Min-max & $72.1-87.5$ \\
\hline
\end{tabular}

\section{Effects of Family Characteristics and Adolescent Characteristics on Cognitive Intelligence and Self-Regulated Learning}

The results (Table 6) showed that family characteristics did not significantly predict cognitive intelligence (Adj. R square $=0.007 ; p>0.05$ ). Other results indicated that maternal education duration negatively predicted adolescent SRL. That is, every time a mother's education increases by 1 year, SRL scores will be reduced by 0.433 . 
Table 6. Effects of family characteristics on cognitive intelligence and self-regulated learning

\begin{tabular}{|c|c|c|c|c|}
\hline \multirow{2}{*}{ Variable } & \multicolumn{2}{|c|}{ Cognitive intelligence } & \multicolumn{2}{|c|}{ Self-regulated learning } \\
\hline & B & $p$-value & B & $p$-value \\
\hline Constant & 8.303 & 0.000 & 422.477 & 0.000 \\
\hline Father's education & 0.033 & 0.410 & 0.156 & 0.379 \\
\hline Mother's education & 0.044 & 0.379 & -0.433 & $0.048 *$ \\
\hline Per capita income & $3.635 \mathrm{E}-8$ & 0.794 & $-1.033 \mathrm{E}-7$ & 0.865 \\
\hline R-square & \multicolumn{2}{|c|}{0.040} & \multicolumn{2}{|c|}{0.050} \\
\hline Adjusted R-square & \multicolumn{2}{|c|}{0.007} & \multicolumn{2}{|c|}{0.017} \\
\hline $\mathrm{F}$ & \multicolumn{2}{|c|}{1.205} & \multicolumn{2}{|c|}{1.525} \\
\hline$p$-value & \multicolumn{2}{|c|}{0.313} & \multicolumn{2}{|c|}{0.214} \\
\hline
\end{tabular}

Note. $\left.{ }^{*}\right)$ significant at $p<0.05,(* *)$ significant at $p<0.001$

Table 7 shows that male adolescents were able to increase the cognitive intelligence score by 0.705 . However, based on the regression test, it was found that individual characteristics had no significant effect on SRL $\left(\mathrm{R}^{2}=0.013 ; p>0.05\right)$. Gender influenced $66 \%$ of adolescent cognitive intelligence $(p<0.05)$.

Table 7. Effects of adolescent characteristics on cognitive intelligence and self-regulated learning

\begin{tabular}{lcccc}
\hline \multirow{2}{*}{ Variable } & \multicolumn{2}{c}{ Cognitive intelligence } & \multicolumn{2}{c}{ Self-regulated learning } \\
\cline { 2 - 5 } & $\mathrm{B}$ & $p$-value & $\mathrm{B}$ & $p$-value \\
\hline Constant & 8.881 & 0.000 & 66.255 & 0.000 \\
Gender & 0.705 & 0.014 & 1.386 & 0.278 \\
\hline R-square & 0.066 & & 0.013 & \\
Adjusted R-square & 0.055 & & 0.002 & \\
F & 6.285 & & 1.192 & \\
-value & 0.014 & & 0.278 & \\
\hline
\end{tabular}

Note. $\left.{ }^{*}\right)$ significant at $p<0.05,(* *)$ significant at $p<0.001$

Effects of Family Characteristics, Adolescent Characteristics, Cognitive Intelligence, and Self-Regulated Learning on Academic Achievement

To determine the effect of family characteristics, individual characteristics, cognitive intelligence, and self-regulated learning on academic achievement, a multiple linear regression test was performed. Table 3 shows that the father's and mother's length of education, age, and cognitive intelligence had a positive effect on adolescent academic achievement. As father and mother's education is getting longer, and cognitive intelligence is increasing, adolescent academic achievement scores will each increase by $0.239,0.261$, and 1.064, respectively. This model as a whole predicts $32.5 \%$ of adolescent academic achievement. 
Table 8. Effects of family characteristics, adolescent characteristics, cognitive intelligence, and self-regulated learning on academic achievement

\begin{tabular}{lcc}
\hline \multirow{2}{*}{ Variable } & \multicolumn{2}{c}{ Academic achievement } \\
\cline { 2 - 3 } Constant & $\mathrm{B}$ & $p$-value \\
Father's education & 64.195 & 0.000 \\
Mother's education & 0.239 & $0.016^{*}$ \\
Per capita income & 0.261 & $0.036^{*}$ \\
Gender & $-7.335 \mathrm{E}-8$ & 0.668 \\
Cognitive intelligence & 0.116 & 0.875 \\
Self-regulated learning & 1.064 & $0.000^{* *}$ \\
R-square & -0.021 & 0.726 \\
Adjusted R-square & 0.370 & \\
F & 0.325 & \\
$p$-value & 8.229 & \\
\hline Note. & $0.000^{*}$ &
\end{tabular}

Note. $\left(^{*}\right)$ significant at $p<0.05,\left(^{* *}\right)$ significant at $p<0.001$

\section{Discussion}

Academic achievement is a result of the learning process. Psychologist Bandura (Santrock, 2003) explains through the Cognitive Social Learning Theory that individuals learn by observing what others do through observational learning. Furthermore, Bandura (Santrock, 2003) explains that behavior, humans and cognition, and the environment interact with each other interactively in the learning process. In other words, the learning process that will produce individual academic achievement involves many factors that do not only originate from the individual's internal self. The process involves a family environment that can be described through family characteristics, individual characteristics such as gender, cognitive intelligence, and self-regulated learning, which are mutually influential factors. Cognitive intelligence in some findings (Hauser, Swell, \& Alwin, 1976; Hauser et al. 1983; Sewell \& Hauser 1975; Sewell et al. 1980 in Jay, 1997) will relate to academic achievement and further educational achievement. In this regard, this study found the cognitive intelligence of adolescents with an average age of 13.9 years included in the average category. Cognitive intelligence consisting of seven dimensions has various achievements. For example, the dimensions of visual memory, vocabulary, and integration of adolescents have poor performance. Teenagers have not been able to recall visual patterns, know the words around them, and have not been able to combine several processes in their daily lives properly. However, in other dimensions such as auditory memory, kinesthetic learning, and concentration of adolescents have had a good performance. This means that adolescents have been able to mention the information they have heard, are able to learn the forms of change around, and are able to pay attention to certain stimulations or stimulations well. Meanwhile, in the auditory sequencing dimension adolescents are able to recall the order of information that they have heard quite well.

Measurement of SRL is intended to measure the ability of individuals themselves to start learning directly in order to obtain the desired goals without relying on teachers, parents or others (Zimmerman, 1989). The results showed that adolescents had a medium 
categorized SRL. That is, adolescents are still not optimally building SRL in motivation and learning strategies to achieve the desired goals. This is evident from the achievements in the subdimension of anxiety about examinations that on average was in a low category. Adolescents with exam anxiety will find it difficult to focus their attention on important points, difficult to organize subject matter, unable to use information codes quickly, difficult to manage study time, unable to use outside resources, such as peers (VanZileTamsen \& Livingston, 1999). However, in the subdimension of orientation extrinsic goals, adolescents had high achievements. This shows that adolescents are more focused on showing their abilities, focus on getting the best value or getting praise from others, focus on proving themselves valuable to others, and/or avoiding negative consequences that may be received from outside (Ames \& Archer, 1988; Elliot \& Church, 1997; Elliot \& Harackiewicz, 1996; Middleton \& Midgley, 1997; Pintrich, 2000).

Other results about SRL on the learning strategy dimension show different things from the motivational dimension. On the dimension of learning strategies, adolescents show nearly even results where each subdimension is in the medium category. However, among the subdimensions, the lowest achievement was the ability of adolescents in time management/learning environments. That is, adolescents have not been able to choose an environment that is conducive to learning, making schedules, planning, and managing effective learning time for themselves (Taylor, 2012). Successful students will be sensitive to their physical learning environment and learning time management (Taylor 2012). Meanwhile, the highest subdimension in the learning strategy dimension is shown by the ability of adolescents to seek help in learning. This, according to Taylor (2012), indicates that adolescents have been able to reach out to mentors and other students who are able to help themselves in the learning process. Adolescents who are able to seek help will have adaptive learning strategies that are able to optimize the learning process (Taylor 2012) and adolescents can enhance their learning experiences when facing difficult tasks through sources of assistance that can be obtained (Ames \& Archer, 1988; Karabenick, 1998; Zimmerman \& Martinez-Pons, 1986 in Taylor, 2012).

Research on the influence of family characteristics, namely the length of father's education, length of mother's education, and income per capita statistically did not affect cognitive intelligence. The results of this study differ from the results of previous studies which state that parental education and family income have a positive relationship with adolescent cognitive abilities (Castillo et al., 2011; McCulloh \& Joshi, 2001). The reason for these differences can be due to family income factors affecting the cognitive intelligence of adolescents through the home environment not examined in this study (McCulloh and Joshi, 2001). In addition, Santrock (2003) further explained that environmental influences are complex influences in which parental achievement (rich and successful/smart) does not necessarily foster adolescent motivation to learn and achieve success (intelligence).

SRL became a part that was also proven to be supported by social support (Zimmerman \& Martinez-Pons 1990). In this study, it was found that maternal education duration had a negative effect on SRL. These results tend to be different from previous studies that mention the social support students receive from parents has a positive effect on the use of independent learning skills (Zimmerman \& Martinez-Pons 1990). The difference with the results of this previous study can be due to families who have 
adolescents tend to be faced with adolescent disobedience that causes parents to behave in a restraint and pressure adolescents to follow the values expected by parents (Santrock, 2003). Pressure makes adolescents unable to build their own regulations through experiments that can build SRL with the optimal fit with themselves.

In this study, the characteristics of adolescents, namely gender proved to affect cognitive intelligence. Male adolescents are more likely to be able to increase cognitive intelligence. According to Nyborg (2005), gender differences have different effects on cognitive intelligence due to greater brain volume so that the cognitive abilities of men are better than women (Nyborg, 2005). Furthermore, another thing that can cause these differences is the difference in motivation, priorities in life, self-confidence and interests (Woolfolk \& Perry, 2012). Zimmerman and Martinez-Pons (1990) found that there are gender differences in SRL strategies where women are significantly more able to maintain and monitor, develop the environment, and make plans and goals that are better than men, this shows that differences in gender can cause differences in SRL. The findings are different from the results of this study. This study found that gender was not a determining factor for SRL in adolescents. The difference in the results of this study could be due to the existence of social support such as teacher and classmates, and/or different classroom settings that also affect the achievements of SRL that are not examined (Zimmerman \& Martinez-Pons, 1990).

Other measurements of cognitive intelligence have been shown to have a positive effect on adolescent academic achievement. This result is in accordance with previous research which found that cognitive intelligence is the best predictor for determining academic achievement in all classes (Laidra et al., 2006). In SRL, the results of the study showed that there was no influence of SRL on academic achievement. This finding was supported by Inpornvijit (2008) who found that SRL had no effect on academic achievement outcomes. These results are not in line with previous research which states that there is a positive relationship between SRL and academic achievement where the research uses different academic achievements (only reading, mathematics, and natural sciences) and the research was conducted in different countries (Hong Kong) (Sui - $\mathrm{Cu} \mathrm{Ho}$, 2005). In this study, cognitive intelligence tends to be more dominant in influencing academic achievement outcomes. Pintrich and De Groot (1990) state that findings of the influence of SRL can be different given the differences in-class assignments and context variables.

Research of Chung (2000) revealed that academic achievement is triggered by internal encouragement and is influenced by external factors. The high level of parental education will generate greater expectations with the presence and assistance of children's school work (Davis-Kean 2005). This is in line with the results of this study which found that parental education and cognitive intelligence had a positive effect on adolescent academic achievement. The results of subsequent studies showed that gender did not appear to influence academic achievement. Furnham et al. (2003) found a strong relationship between gender and academic achievement. This influence can be caused by differences between women and men where women spend more time studying while men tend to be lazy, but this cannot prove that men are less intelligent than women (Kumar \& Lal, 2006). However, the research of Naderi et al. (2010) found that the influence and gender differences on academic achievement are still not consistent with previous studies. 


\section{Conclusion and Recommendation}

\section{Conclusion}

Research shows that the average parents of adolescents have a high school education level with an average income of $\mathrm{Rp} 1,158,081.70$. The average age of adolescents is 13.9 years with the largest percentage in this study being female. Adolescent cognitive intelligence scores are in the average category with the ability of adolescents to reiterate the information they have heard, learn the forms of change, and pay attention to the stimulus received has been good. But, some abilities categorized below average are the ability to recall visual patterns, understand the words around them, and combine a number of processes whereas the ability of adolescents to recall information sequences is categorized quite good. Adolescent self-regulated learning is in the average category with quite good achievements in the ability of intrinsic goal orientation, the value of the task, control of the trust in learning, practice, elaboration, organizing, critical thinking, metacognition in self-regulation, an arrangement in trying, and learning from peer groups. The ability of self-regulated learning in the subdimension of extrinsic goal orientation and the search for help, test anxiety, and time management/learning environment show very good achievements. The academic achievements of adolescents tend to be above average.

The length of parental education and income per capita does not affect cognitive intelligence. The partial analysis shows that a mother's education negatively affects adolescent self-regulated learning but other characteristics have no effect. The characteristics of adolescents, namely age and gender only affect adolescent cognitive intelligence but not adolescent self-regulated learning. Regression analysis shows that parental education, adolescent age, and cognitive intelligence alone influence adolescent academic achievement while per capita income, gender, and self-regulated learning have no effect on adolescent academic achievement.

\section{Recommendation}

Considering the results of the study indicate that maternal education negatively influences adolescent self-regulated learning, it is suggested that mothers with higher education to further develop intrinsic motivation in adolescents through understanding ideals. In addition, mothers with higher education are expected to be better in directing adolescents to manage the learning environment of adolescents and foster self-confidence so that adolescents do not have excessive anxiety when facing exams. Given that adolescent girls have lower cognitive scores, parents and schools need to supervise adolescent girls in order to further improve their ability to recall visual patterns, understand the meaning of words around them, and combine several existing processes to help optimize performance their cognitive.

Considering parental education has an effect on adolescent academic achievement, parents with less education can expand their education and knowledge by adding nonformal education or through media that is currently easily accessible. Parents and schools also need to increase their attention given that cognitive intelligence will positively 
influence academic achievement. Parents and schools can provide oversight of the environment such as peers who are suspected of influencing their academic achievement since adolescence begins to have a more intensive orientation to social relations.

\section{References}

Amalia, R., \& Latifah, M. (2019). Parental support, academic emotion, learning strategy, and academic achievement on first year student. Journal of Family Sciences, 4(1), 41-53. https://doi.org/10.29244/jfs.4.1.41-53

Ames, C., \& Archer, J. (1988). Achievement goals in the classroom: students' learning strategies and motivation processes. Journal of Educational Psychology, 80(3): 260267. https://doi.org/10.1037/0022-0663.80.3.260

Castillo, R., Ruiz, J. R., Chillon, P., Jimenez-Pavon, D., Esperanza-Diaz, L., Moreno, L. A., \& Ortega, F. B. (2011). Associations between parental educational/occupational levels and cognitive performance in Spanish adolescents: The AVENA study. Journal of Psicothema, 23(3), 349-355.

Chung, M. K. (2000). The development of self-regulated learning. Journal of Asia Pasific Education Review, 1(1), 55-56. https://doi.org/10.1007/BF03026146

Clemons, T. L. (2008). Underachieving gifted students: A social cognitive model. The National Research Centre on the Gifted and Talented. Virginia: University of Virginia.

Davis-Kean, P. E. (2005). The influence of parent education and family income on child achievement: The indirect role of parental expectations and the home environment. Journal of Family Psychology, 19(2), 294-304. https://doi.org/10.1037/08933200.19.2.294

Diniz, A., Pocinho, M. D., Almeida, L. S. (2011). Cognitive abilities, sociocultural background, and academic achievement. Psicothema, 23(4), 695-700.

Elliot, A., \& Church, M. (1997). A hierarchical model of approach and avoidance achievement motivation. Journal of Personality and Social Psychology, 72(1), 218232.

Elliot, A., \& Harackiewicz, J. (1996). Approach and avoidance achievement goals and intrinsic motivation: A mediational analysis. Journal of Personality and Social Psychology, 70(3), 461-475. https://doi.org/10.1037/0022-3514.70.3.461

Furnham, A., Chamorro-Premuzic, T., McDougall, F. (2003). Personality, cognitive ability, and beliefs about intelligence as predictors of academic performance. Journal of Learning and Individual Differences, 14, 49-66.

Inpornvijit K. (2008). Effects of feedback on self-regulated learning strategy use and academic performance (Doctoral dissertation). University of South Alabama, Alabama.

Jay, T. (1997). Gender of siblings, cognitive achievement, and academic performance: Familial and Nonfamilial Influences on Children. Journal of Marriage and the Family, 59(2).

Karabenick, S. A. (Ed.). (1998). Strategic Help Seeking: Implications for Learning and Teaching. New Jersey: Lawrence Erlbaum Associates Publishers. 
Kumar, R., Lal, R. (2006). The role of self-efficacy and gender difference among adolescents. Journal of the Indian Academy of Applied Psychology, 63(1), 128-138.

Kurman, J. (2004). Gender, self enhancement, self regulation of learning behaviors in junior high school. ProQuest Sociology, 50(9/10), 725.

Laidra, K., Pullmann, H., \& Allik, J. (2006). Personality and intelligence as predictors of academic achievement: a cross-sectional study from elementary to secondary school. Journal of Personality and Individual Differences, 42(3), 441-451. https://doi.org/10.1016/j.paid.2006.08.001

Latifah, M., \& Dina, N. N. (2002). Panduan Tes Kemampuan Kognitif Anak Usia Sekolah (10-11 tahun). Bogor: IPB Press.

Latipah, E. (2010). Strategi self regulated learning dan prestasi belajar: Kajian meta analisis. Jurnal Psikologi, 37(1), 110-129. https://doi.org/10.22146/jpsi.7696

McCulloh, A., \& Joshi, H. E. (2001). Neighbourhood and family influences on the cognitive ability of children in the british national child development study. Journal of Social Science Media, 53(5), 579-591. https://doi.org/10.1016/S02779536(00)00362-2

Mega, C., Ronconi, L., \& De Beni, R. (2014). What makes a good student? How emotions, self-regulated learning, and motivation contribute to academic achievement. Journal of Educational Psychology, 106(1), 121. https://doi.org/10.1037/a0033546

Middleton, M., \& Midgley, C. (1997). Avoiding the demonstration of lack of ability: An underexplored aspect of goal theory. Journal of Educational Psychology, 89(4), 710-718. https://doi.org/10.1037/0022-0663.89.4.710

Naderi, H., Abdullah, R., Aizan, H. T., \& Sharir, J. (2010). Intelligence and academic achievement: An investigation of gender differences. Life Science Journal, 7(1).

Novianti, N., Latifah, M., \& Hernawati, N. (2018). Mengoptimalkan faktor diri dan keluarga dalam prestasi akademik remaja. Jurnal Ilmu Keluarga \& Konsumen, 11(1), 60-73. https://doi.org/10.24156/jikk.2018.11.1.60

Novita, L., \& Latifah, M. (2014). Strategi pengaturan diri dalam belajar sebagai mediator harapan orang tua dan motivasi intrinsik terhadap prestasi akademik. Jurnal Ilmu Keluarga \& Konsumen, 7(3), 143-1. https://doi.org/10.24156/jikk.2014.7.3.143

Nyborg, H. (2005). Sex-related differences in general intelligence g, brain size, and social status. Journal of Personality and Individual Differences, 39, 497-509. https://doi.org/10.1016/j.paid.2004.12.011

Organization for Economic Co-operation and Development. (2018). Education at a Glance. Retrieved from https://www.oecd-ilibrary.org/education/education-at-aglance-2018_eag-2018-en

Pintrich, P. R., \& De Groot, E. V. (1990). Motivational and self-regulated learning components of classroom academic performance. Journal of Educational Psychology, 82(1), 33-40. https://doi.org/10.1037/0022-0663.82.1.33

Pintrich, P., Smith, D., Garcia, T., \& McKeachie, W. (1991). A manual for the use of the Motivated Strategies for Learning Questionnaire (MSLQ) (Grant No. OEM-860010). Retrieved from https://files.eric.ed.gov/fulltext/ED338122.pdf 
Pintrich, P. (2000). Multiple goals, multiple pathways: The role of goal orientation in learning and achievement. Journal of Educational Psychology, 92(3), 544-555. https://doi.org/10.1037/0022-0663.92.3.544

Riley. S. (1992). Learning Process Skills (Riley Inventory of Basic Learning Skills). California: Academic Therapy Publications.

Rohde, T. E., \& Thompson, L. A. (2007). Predicting academic achievement with cognitive ability. Intelligence, 35(1), 83-92. https://doi.org/10.1016/j.intell.2006.05.004

Rosopa, P. J., \& Schroeder, A. N. (2009). Core self-evaluations interact with cognitive ability to predict academic achievement. Personality and Individual Differences, 47(8), 1003-1006. https://doi.org/10.1016/j.paid.2009.07.028

Santrock, J. W. (2003). Adolescence: Perkembangan Remaja (6th ed.). Jakarta: Erlangga.

Santrock, J. W. (2011). Educational Psychology (5th ed.). McGraw-Hill.

Situmorang, Z. R. D., \& Latifah, M. (2014). Pengaruh dukungan sosial, konsep diri, dan strategi pengaturan diri dalam belajar terhadap prestasi akademik. Jurnal Ilmu Keluarga dan Konsumen, 7(3), 154-163. https://doi.org/10.24156/jikk.2014.7.3.154

Stull, J. C. (2013). Family socioeconomic status, parent expectations, and a child's achievement. Research in Education, 90(1), 53-67. https://doi.org/10.7227/RIE.90.1.4

Sui-Chu Ho, E. (2005). Self regulated learning and academic achievement of Hongkong Secondary School Students. Education Journal, 32(2).

Taylor, R. T. (2012). Review of the Motivated Strategies For Learning Questionnaire (MSLQ) using reliability generalization techniques to assess scale reliability (Doctoral dissertation, Auburn University, United States). Retrieved from https://etd.auburn.edu/handle/10415/3114

Theresya, J., Latifah, M., \& Hernawati, N. (2018). The effect of parenting style, selfefficacy, and self-regulated learning on adolescents' academic achievement. Journal of Child Development Studies, 3(1), 28-43. https://doi.org/10.29244/jcds.3.1.28-43

VanZile-Tamsen, C., \& Livingston, J. (1999). The differential impact of motivation on the selfregulated strategy use of high- and low-achieving college students. Journal of College Student Development, 40(1), 54-60.

Woolfolk, A., Perry, N. E. (2012). Child and Adolescent Development. New Jersey: Pearson Education, Inc.

Zimmerman, B. J. (1989). Social cognitive views of self-regulated academic learning. Journal of Educational Psychology, 81(3), 329-339. https://doi.org/10.1037/00220663.81.3.329

Zimmerman, B. J., \& Martinez-Pons, M. (1990). Student differences in self-regulated learning: Relating grade, sex, and giftedness to self-efficacy and strategy use. Journal of Educational Psychology, 82(1), 51-59. https://doi.org/10.1037/00220663.82.1.51

Zimmerman, B. J. (2000). Attaining self-regulation: A social cognitive perspective. In M. Boekaerts, P. R. Pintrich, \& M. Zeidner (Eds.), Handbook of Self-regulation. Academic Press. https://doi.org/10.1016/B978-012109890-2/50031-7

Zimmerman, B. J. \& Schunk, D. H. (Eds.) (2001). Self-regulated Learning and Academic Achievement: Theoretical Perspectives (2nd ed.). New Jersey: Lawrence Erlbaum Associates Publishers. 